\section{PP-529 一般高龄者における尿失禁の実態調査}

\section{東京都江東区深川保健相談所}

渡瀬 博俊

【目的】高歯化に伴う膀胱機能の低下ゃ下部尿路閉塞性疾患 の増加等の影響により、尿失禁をはじめとした排尿症状が 出現しやすくなることが考えられている。今回地域に在住 する一般高齢者の尿失禁症状の出現状況と加齢の影響を検 証した。方法】平成 16 年 10 月に東京都江東区内に在住す る 65 歳以上の高齢者を対象としたアンケート調査におい て 2310 名より回答が得られた。そのうち尿失禁の頻度と外 出への影響を調查した。結果】尿失禁の頻度について、症 状がない」と回答した者の割合は男性で約 $67 \%$ であったの に対し、女性では同約 $45 \%$ であった。また尿失禁の頻度が 高いものほど外出への影響が大きく、年に数回程度の尿失 禁者では、「外出にほとんど影響しない」と回答した割合が 90\% 程度であったのに対し、尿失禁の頻度がほぼ毎日であ る場合、同 $40 \%$ 程度まで低下していた。結論】今回の結果 において、尿失禁の程度が外出へ与える影響が示唆されて おり、生活の質を維持する上で尿失禁が強い影響を与えて いると考えられた。尿失禁の回数が多い場合は、臨床治療 による尿失禁症状の軽減により、外出頻度の増加などに結 びつくことが期待され、QOL の改善や外出時の運動などの 二次的効果により、高齢期の体力維持にも有用となる可能 性が考えられた。

\section{PP-531}

\section{小児陰囊水腫における自然治癒時期の予} 測方程式

\section{豊川市民病院泌尿器科"1, 名古屋市立大学大学院医学研究 科腎・泌尿器科学分野 ${ }^{2}$}

津ヶ谷 正行 $^{1)}$, 伊藤 尊一郎 ${ }^{1)}$, 遠藤 純央 ${ }^{1)}$, 岡田 真介 ${ }^{2)}$, 伊藤 恭典 ${ }^{2}$

【目的】小児の陰囊水腫はしばしば自然治癒する。自然治癒 の時期が予測できれば臨床的に有用であるため、推計学的 に検討した。対象と方法】過去 5 年間に当科を受診した陰 囊水腫または精索水腫は 92 例、101 水腫で、その中で手術 症例 28 例、経過観察中 9 例、自然治癒は 55 症例、 64 水腫 であった。自然治癒症例を対象とし、自然治癒時期の予測 について推計学的に検討した。結果】自然治癒水腫の発見 時年齢は 0 8.8 歳、(平均 \pm 標準偏差：1.8 \pm 2.0 歳)、初診時 年齢は 0 9.7 歳、 $(2.4 \pm 2.5$ 歳) であった。治癒時の年齢は 0.2 9.8 歳、(3.0 2.7 歳)であった。自然治癒した水腫の初診 時年齢が 1 歳未満の群は 1 歳以上の群より初診から消失す るまでの期間が短かった $(\mathrm{p}=0.0468)$ 。そして自然治癒した 水腫の発見時年齢ならびに初診時年齢と治癒年齢との間に それぞれ良好な正の相関が認められた（Y=1.05X+1.29、 $\mathrm{R}=0.763, \mathrm{p}<0.0001 、 \mathrm{n}=64) 、(\mathrm{Y}=1.052 \mathrm{X}+0.7, \mathrm{R}=0.932$, $\mathrm{p}<0.0001 、 \mathrm{n}=64)$ 。【考察・結語】上記結果から自然治瘉ま での期間は 1 歳以上の群より 1 歳未満群の方が短く、そし て前記回帰方程式は自然治癒の時期を予測でき、有用と考 えられた。

\section{PP-532}

急性陰囊症における超音波カラードプラ 法の有用性の検討

\footnotetext{
仙台赤十字病院泌尿器科"，大崎市民病院2), 東北大学大 学院泌尿器科学分野 ${ }^{3)}$

太田 章三1), 栫井 成彦 ${ }^{1)}$, 山田 成幸 ${ }^{2)}$, 川守田 直樹3), 沼畑 健司 ${ }^{3)}$

目的：急性陰囊症で、精索捻転、精巣垂捻転、精巣上体炎などを すばやく鑑別するのは重要である。我々は急性陰囊症に対し超音 波カラードプラ法で鑑別診断を行っており、その有用性について 検討した。対象、方法：2001 年 11 月から 2006 年 9 月までの 5 年間に、陰囊部の疼痛、腫大などを主訴に当院を受診した患者で、 超音波カラードプラ法を施行した 24 例を対象とした。Toshiba 社製 SSA-550A $12 \mathrm{MHz}$ リニアプローベを用い、超音波カラード プラ法を施行した。血流の状態は健側との比較で判断した。年齢 は 0-26 歳で、右 13 例、左 11 例であった。結果 : 1)患側精巣の 血流消失を認め精索捻転と診断した 10 例で手術を施行。9 例で 精索捻転 (5 例精巣固定、4 例精巣摘出)、1 例は精巣垂捻転であっ た。2) 患側精巣の血流が増加あるいは不変で、精巣垂 (精巣上体 垂)捻転と診断したのは 13 例。そのうち 5 例で保存的治療が選択 され、8例では痛みの増強、家族の希望などで手術を施行した。 手術例 8 例のうち 1 例は捻転解除状態の精索捻転症、 7 例は精巣 垂 (精巣上体垂) 捻転であった。3) 患側精巣の血流が不変で、臨 床的に捻転解除状態の精索捻転と䛦断した 1 例は手術の結果精 宩垂捻転であった。結論：超音波カラードプラは急性陰囊症の鑑 別診断に簡便かつ非常に有用な方法であった。
} 